\title{
EFFECTIVENESS OF COOPERATIVE LEARNING TYPE TAI (TEAM- ASSISTED INDIVIDUALIZATION) AND NHT (NUMBER HEAD TOGETHER) TYPE AGAINST MATHEMATICS LEARNING OUTCOMES OF SMPN 3 JETIS
}

\author{
Moh Rizki Yuniardi Basuni ${ }^{\mathrm{a}}$, Aris Thobirin ${ }^{\mathrm{b}}$ \\ Program Studi Pendidikan Matematika Universitas Ahmad Dahlan \\ Jalan Ring Road Selatan, Tamanan, Banguntapan, Bantul Yogyakarta

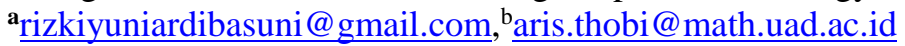

\begin{abstract}
The study was conducted on the grounds that learning commonly applied in Jetis Middle School 3 in Bantul Regency tends to be teacher-centered, students become passive and less involved in the learning process, so learning models that involve students are needed. One learning model that can provide opportunities for students to be active in the Cooperative Learning Model Type TAI (TeamAssisted Individualization) and NHT type (Number Head Together). This study aims to determine the effectiveness of Cooperative Learning Type TAI (Team-Assisted Individualization) and NHT type (Number Head Together) on the mathematics learning outcomes of class VII students of SMP N 3 Jetis Bantul district, even semester 2015/2016 academic year on the subject of flat building rectangular. The population in this study were all VII graders in the even semester of SMP N 3 Jetis, Bantul Regency in the 2015/2016 academic year which were divided into 7 classes namely VII A, VII B, VII C, VII D, VII E, VII F, and VII G which a total of 212 students. The samples were taken in 3 classes with a purposive sampling technique, obtained class VII B as Experiment Class I, class VII A as Experimental Class II, and Class VII C as Control Class. The data analysis technique used for the prerequisite test includes the normality test with the Chi-Square formula, the homogeneity test with the Bartlett test, and the hypothesis test includes the F Test and the Least Significant Different (LSD) test. The results at a significant level of $5 \%$ and $\mathrm{df}=(2,94)$ indicate $(1)$ that at least two classes have differences in mathematics learning outcomes of students who use the Cooperative Learning Model Type TAI, NHT type, and direct learning models. This is indicated by the value $F_{\text {count }}=11,98102$ and $F_{\text {table }}=3,10733$ so $F_{\text {count }}>F_{\text {table }}$ and (2) Classes that use the Cooperative learning model Type TAI are more effective than those using the NHT type learning model on learning outcomes and classes that use NHT type learning are more effective than those that use direct learning models on learning outcomes. This is indicated by the results of the LSD hypothesis test where a significant level of $5 \%$ and 94 degrees of freedom were obtained in case I $\left|\bar{y}_{1}-\bar{y}_{2}\right|=7,92$ and LSD $=6,35$ so then $\left|\bar{y}_{1}-\bar{y}_{2}\right|>\operatorname{LSD}$ then $H_{0}$ rejected and $\bar{y}_{1}=80,00$ and $\bar{y}_{2}=$ 72,08 means $\mu_{1}>\mu_{2}$. In case II $\left|\bar{y}_{1}-\bar{y}_{3}\right|=15,625$ and $\operatorname{LSD}=6,35$ so then $\left|\bar{y}_{1}-\bar{y}_{3}\right|>\operatorname{LSD}$ then $H_{0}$ rejected and $\bar{y}_{1}=80,00$ and $\bar{y}_{3}=64.375$ means $\mu_{1}>\mu_{3}$. While in the case III $\left|\bar{y}_{2}-\bar{y}_{3}\right|=7,708$ and $\operatorname{LSD}=6,30$ so then $\left|\bar{y}_{2}-\bar{y}_{3}\right|>\operatorname{LSD}$ so $H_{0}$ rejected and $\bar{y}_{2}=72,08$ and $\bar{y}_{3}=64.375$ means $\mu_{2}>\mu_{3}$ . It concluded that $\mu_{1}>\mu_{2}>\mu_{3}$.
\end{abstract}

Keywords: $\quad$ Effectiveness, Cooperative Learning Model TAI (Team Assisted Individualisation), NHT (Number Head Together), and direct learning model.

\section{INTRODUCTION}

An advanced nation is certainly an ideal that every country in the world wants to achieve. The progress of a nation can be determined by education. Quality education will produce quality Human Resources (HR) as well. Education is very important and cannot be separated from life. Law No. 20 of 2003 concerning the national education system Article 1 Paragraph 1 states that: Education is a conscious and planned effort to create a learning atmosphere and learning process so that students actively develop their potential to have religious-spiritual strength, self-control, personality, intelligence, noble character and the skills needed by him, the community, the nation, and the country.

The right learning model is needed by a teacher to achieve learning goals effectively and efficiently. The learning model that is applied in a teaching is said to be effective when producing something in accordance with what is expected or in other words the learning goal is achieved ie students are able to master the subject matter being taught, while the learning model is said to be effective if its 
application in producing something expected is relatively successful. Some cooperative learning models used to improve learning outcomes are cooperative learning types TAI (Team-Assisted Individualization) and NHT (Number Head Together) models.

The identification of problems in this study is 1) Mathematics is considered as one of the difficult lessons. 2) Lack of participation from students in the learning process of mathematics in the classroom. 3) Not yet applied mathematical learning models that can improve student learning outcomes. 4) Low student learning outcomes in mathematics learning. This is indicated by the average UTS score which is still low and has not yet reached the KKM.

The problems in this study are: 1) Are there differences in mathematics learning outcomes between those who use cooperative learning models Type TAI, NHT and Direct Learning Models in VII grade students of Even Semester SMPN 3 Jetis in Bantul 2015/2016 Academic Year? 2) Which is more effective, between Cooperative Learning Model Type TAI, NHT and Direct Learning Model Against Mathematics Learning Outcomes of Grade VII Students Even in Semester SMPN 3 Jetis in Bantul Regency 2015/2016 Academic Year?

The objectives of this study are 1) To determine whether there are differences in mathematics learning outcomes between those using cooperative learning models Type TAI, NHT and Direct Learning Models in VII Grade Even Semester Students of SMPN 3 Jetis, Bantul Regency 2015/2016 Academic Year. 2) To determine the effectiveness between cooperative learning models of Type TAI, NHT and Direct Learning Models of Mathematics Learning Outcomes of VII Grade Students in Even Semester of SMPN 3 Jetis, Bantul Regency, 2015/2016 Academic Year.

\section{THEORY}

Some opinions according to experts about the understanding of mathematics in Suherman, Erman et al (2003: 16-17) as follows: 1) According to James said that mathematics is the science of logic regarding the form, arrangement of magnitudes, and concepts that relate to one another a large number is divided into three parts, namely algebra, analysis, and geometry, 2) According to Johnson and Rising said that mathematics is a mindset, an organizing pattern, logical proof, mathematics is a language that uses carefully defined terms, clear, and accurate, representations with symbols and dense, more in the form of symbolic language about ideas than about sounds, 3) According to Reys et al. said that mathematics is the study of patterns and relationships, a way or pattern of thinking, an art, a language, and a tool, and 4) According to Kline said that mathematics is not alone knowledge that can be perfect because of him itself, but the existence of mathematics is primarily to help humans understand and master social, economic and natural problems.

According to Suherman, Erman et al (2003: 55-58), school mathematics is mathematics taught in schools, namely mathematics taught in elementary education (elementary and middle school) and secondary education (high school and vocational school). School mathematics consists of selected parts of mathematics in order to develop abilities and form a person and combine with the development of science and technology. School mathematics still has characteristics, namely having abstract event objects and consistent deductive mindset.

The function of mathematics subjects as tools, mindset, and science. These three functions should be used as references in learning mathematics at school. According to Ibrahim and Suparni (2008: 64), Learning can be defined as follows: an effort made by someone to obtain a change in behavior consciously from the results of their interaction with the environment. This definition contains two essential things, namely: First, that learning is an attempt to achieve a certain goal, namely to get a change in behavior. Second, changes in behavior that occur must be conscious. Thus, someone is said to learn if after learning activities he realizes that in him there has been a change. According to Suprijono, Agus (2009: 3), Learning is the process of gaining knowledge. Learning as a concept gets a lot of knowledge in practice. According to Suherman, Erman et al (2003: 298-299), Learning mathematics is a discipline that studies the procedures of thinking and processing logic, both quantitatively and qualitatively. Learning mathematics is laid the basis of how to develop ways of thinking and acting through rules called propositions 
(demonstrable) and axioms (without proof). Mathematics learning is expected to end with a comprehensive and holistic understanding of students (across topics even across studies if possible) about the material presented. According to Winataputra in Hamzah, Ali (2014: 42), Learning refers to all activities that directly influence student learning. The word learning is a term used to indicate teacher and student activities or activities of lecturers and students. Before the term teaching and learning process is known, the word learning can be said to be taken from the word instruction which means a series of activities designed to allow learning to occur in students. According to Arends in Suprijono, Agus (2009: 46), the learning model refers to the approach that will be used, including the learning objectives, the stages in learning activities, the learning environment, and classroom management. Learning models can be defined as conceptual frameworks that describe systematic procedures in organizing learning experiences to achieve learning goals. Through the learning model, the teacher can help students get information, ideas, skills, ways of thinking, and expressing ideas. The learning model serves as a guide for learning designers and teachers in planning teaching and learning activities. According to Suprijono, Agus (2009: 46), direct learning or direct instruction is known as active teaching. In the teaching style where the teacher is actively involved in carrying out the contents of the lesson to students and teaches it directly to the whole class. Direct learning is designed for mastering procedural knowledge, declarative knowledge (factual knowledge) and various skills. Direct learning is intended to complete two learning outcomes, namely the mastery of well-structured knowledge and mastery of skills. With Phases of Direct Learning Models, namely: 1) Phase 1: Establishing Sets (Delivering goals and preparing students), 2) Phase 2: Demonstrating (Demonstrating knowledge or skills), 3) Phase 3: Guided Practice (Guiding training), 4) Phase 4: Feedback (Checking understanding and member feedback), and 5) Phase 5: Extended Practice (Providing opportunities for further training and application). According to Isjoni (2010: 14), cooperative learning is one form of learning based on constructivist understanding. Cooperative learning is a learning strategy with a number of students as members of small groups with different levels of ability.

Some opinions about cooperative learning in Isjoni (2010: 14-15)

1) Slavin, cooperative learning is a learning model where students learn and work in small groups collaboratively whose members are 4-6 people with a heterogeneous group structure.

2) Sunal and Hans, cooperative learning is an approach or set of strategies specifically designed to encourage students to work together during the learning process.

3) Stahl, cooperative learning can improve student learning better and improve attitudes to help in social behavior.

According to Robert Slavin in Huda, Miftahul (2013: 200), Team-Assisted Individualization (TAI) is a pedagogic program that seeks to adapt learning to students' individual academic differences. Development of TAI can support classroom practices, such as student grouping, ability grouping in classrooms, programmed teaching, and computer-based teaching. The aim of TAI is to minimize individual teaching that has proved to be less effective but also aimed at increasing students' knowledge, abilities, and motivation with group learning. There are several benefits of TAI that enable it to meet effective learning criteria. Among them are 1) minimizing teacher involvement in routine inspection and management, 2) involving teachers to teach heterogeneous small groups, 3) facilitating students to implement it because operational techniques are quite simple, 4) motivating students to learn the materials provided with fast and accurate, without shortcuts, and 5) allows students to work with other different students to create a positive attitude between them. The steps of TAI learning include concrete steps in implementing the program in the classroom: a) Team - In TAI, students are divided into teams of 4 - 5 members, as in STAD and TGT. b) Placement Test - Students are given a pre-test. They are placed at appropriate levels in individual programs based on their performance on this test. c) Material - Students learn the subject matter to be discussed. d) Group Learning - Students do group learning with their colleagues in a team. e) Scores and Recognition - The work results of students are scored at the end of teaching, and each team that meets the criteria as a "super team" must get recognition from the teacher. f) 
Teaching Groups - Teachers teach each group about the material discussed. g) Fact Tests - The teacher asks students to work on tests to prove their true abilities. (Slavin, 1984)

According to Shoimin, Aris (2014: 107), Model Numbered Head Together (NHT) refers to student group learning, each member has a different task section (questions). For example, in reproductive learning that studies the process of breeding plants and animals more refers to social interaction so that numbered head together learning can improve social relations between students. According to Shoimin, Aris (2014: 108), Numbered head together is a group learning model in which each group member is responsible for the group's assignments, so there is no separation between one student and another student in one group to give and receive one with others. NHT Steps: 1) Students are divided into groups. Each student in each group gets a number. 2) The teacher gives the assignment and each group does it. 3) The group discusses the correct answer and ensures that each group member can do it / know the answer well. 4) The teacher calls one of the student numbers and the number called out of the group reports or explains the results of their collaboration. 5) Response with other friends, then the teacher points to another number. 6) Conclusion.NHT Strengths, 1) Every student is ready. 2) Can discuss it seriously. 3) Smart students can teach less intelligent students. 4) There is intense interaction between students in answering questions. 5) No students dominate in groups because there are restrictive numbers. While the lack of NHT, 1) Not too suitable to be applied in a large number of students because it requires a long time. 2) Not all group members are called by the teacher because of the possibility of limited time.

According to Mulyasa, E (2005: 82), Effectiveness is the suitability between people who perform tasks with the intended target. Effectiveness is also interpreted as how an organization succeeded in utilizing and obtaining resources in an effort to realize operational goals. According to Purwanto, Ngalim (2012: 33), "Learning outcomes tests are tests that are used to assess the results of lessons that have been given by the teacher to students, or by lecturers to students, within a certain period of time". Referring to Gagne's thought in Suprijono, Agus (2009: 5-6) learning outcomes in the form of a) Verbal information that is the ability to express knowledge in the form of language, both oral and written. b) Intellectual skills, namely the ability to present concepts and symbols. c) Cognitive strategies, namely the ability to channel and direct cognitive activities themselves. d) Motor skills, namely the ability to carry out a series of physical movements in affairs and coordination, so as to realize the automatism of physical motion.

\section{METHODS}

This research is a quasi-experimental design in the form of Pretest-Posttest Control Group Design by taking place in SMPN 3 Jetis, Bantul in the even semester of the 2015/2016 school year. The population in this study were all students of class VII of SMPN 3 Jetis, Bantul which consisted of 7 classes. While the sample in this study, taken 3 classes, namely VII A, VII B, and VII C, using a purposive sampling technique. In this study, the data collection techniques used were test techniques. Test techniques are used to measure learning outcomes in mathematics learning. The types of tests that will be used are pretest and posttest. Pretest is a test given to students before treatment, to collect data on initial abilities. While posttest is a test given to students after the existence of a new treatment during the research process. The test used is the analysis prerequisite test by testing the normality of the Chi-square formula and the homogeneity test of the Bartlet-test formula. The research hypothesis test uses ANOVA with the F test. The test after ANOVA is used LSD (Least Significance Different) test to find out the learning approach that has the most significant effect on students' mathematics learning outcomes.

\section{RESULTS AND DISCUSSION}

\section{A. Research Results}

Based on the results of the initial ability test students of class VII A, VII B, and VII C of SMP Negeri 3 Jetis Bantul showed a low average initial ability result. The description of the value of students' initial abilities can be seen in Table 1 . 
Table 1. Summary of Data Descriptions of Early Mathematical Capabilities

\begin{tabular}{|l|c|c|c|}
\hline \multicolumn{1}{|c|}{ Parameter } & VII A & VII B & VII C \\
\hline The highest score & 66,67 & 66,67 & 60,00 \\
\hline Lowest value & 26,67 & 20,00 & 20,00 \\
\hline Average value & 42,292 & 38,49 & 42,5 \\
\hline Standard deviation & 8,9644 & 11,6822 & 10,91525 \\
\hline
\end{tabular}

Based on the posttest results of the experimental class students of the TAI learning model (VII B), the NHT learning model (VII A) and the control class with direct learning (VII C) in Jetis Bantul 3 Public Middle School showed the average posttest results showed a good average. The description of the value of student mathematics learning outcomes can be seen in Table 2 .

Table 2. Summary of Description of Data on Mathematics Learning Outcomes

\begin{tabular}{|l|c|c|c|}
\hline \multicolumn{1}{|c|}{ Parameter } & TAI & NHT & Direct \\
\hline The highest score & 93,33 & 86,67 & 86,67 \\
\hline Lowest value & 46,67 & 33,33 & 26,67 \\
\hline Average value & 78,925 & 72,083 & 64,375 \\
\hline Standard deviation & 11,6808 & 11,5787 & 14,3364 \\
\hline
\end{tabular}

\section{B. Test Prerequisites}

The summary of the results of the normality of learning outcomes can be seen in Table 3 .

Table 3. Summary of Normality Test Results of Mathematics Learning Outcomes Data

\begin{tabular}{|l|c|c|c|}
\hline \multirow{2}{*}{ Parameter } & \multicolumn{3}{|c|}{ Experiment Class } \\
\cline { 2 - 4 } & TAI & NHT & Direct \\
\hline $\mathrm{X}_{\text {count }}^{2}$ & 7,4383 & 3,3929 & 2,0606 \\
\hline $\mathrm{X}_{\text {table }}^{2}$ & 7,814 & 7,814 & 7,814 \\
\hline Significant level & $5 \%$ & $5 \%$ & $5 \%$ \\
\hline$d f(\mathrm{k}-1)$ & 3 & 3 & 3 \\
\hline Testing Criteria & \multicolumn{3}{|c|}{$\mathrm{X}_{\text {count }}^{2}<X_{\text {table }}^{2}$} \\
\hline Information & Normal & Normal & Normal \\
\hline
\end{tabular}

The summary of the results of the initial homogeneity test can be seen in table 4 .

Table 4. Summary of Homogeneity Test Results for Data on Mathematics Learning Outcomes

\begin{tabular}{|l|c|}
\hline \multicolumn{1}{|c|}{ Parameter } & Value \\
\hline $\mathrm{X}_{\text {count }}^{2}$ & 1,874973 \\
\hline $\mathrm{X}_{\text {table }}^{2}$ & 5,9915 \\
\hline Significant level & $5 \%$ \\
\hline$D f(\mathrm{k}-1)$ & 2 \\
\hline Testing Criteria & $\mathrm{X}_{\text {count }}^{2}<X_{\text {table }}^{2}$ \\
\hline Information & Homogeneous \\
\hline
\end{tabular}

\section{Test the Hypothesis}

The summary of the results of the test results learning hypothesis test.

Table 5. Summary of Hypothesis Test Results

\begin{tabular}{|c|c|c|c|c|c|}
\hline Source Of Variance & JK & Df & $\begin{array}{c}\text { Mean } \\
\text { quadrate }\end{array}$ & $\boldsymbol{F}_{\text {count }}$ & \multirow{2}{*}{$\boldsymbol{F}_{\text {table }}$} \\
\hline Treatment & 3339,7941 & 2 & 1669,897 & \multirow{2}{*}{9,70214} & \multirow{2}{*}{3,10733} \\
\hline Error & 15834,706 & 92 & 172,1164 & & \\
\hline Total & 19174,5 & 94 & & & \\
\hline
\end{tabular}


Table 5 shows the results : $F_{\text {count }}>F_{\text {table }} H_{0}$ is rejected.

Conclusion: minimum of two classes there are differences in mathematics learning outcomes in both classes using Type TAI, classes using NHT Types and classes that use direct learning in Jetis Bantul 3 Public Middle School in the academic year 2015/2016.

The results of the hypothesis state that there are differences in the influence of the use of the TAI learning model, the NHT learning model, and direct learning on the mathematics learning outcomes of seventh graders in the semester of SMPN 3 Jetis Bantul in the academic year 2015/2016. The test after Anava was conducted to find out the learning approach that had the most significant influence on students' mathematics learning outcomes. The test after Anava used was LSD (Least Significance Different) test. Based on the LSD test the following results are obtained:

1) Comparison between the TAI experimental class and NHT experimental class has an average difference of 6.84 greater than LSD which is 6.58. This means that the TAI experimental class is more effective than the NHT experimental class on learning outcomes. 2) Comparison between the TAI experimental class and the direct learning control class has an average difference of 14.54 which is greater than LSD which is 6.58. This means that the TAI experimental class is more effective than the direct learning control class for learning outcomes. 3) Comparison between the NHT experimental class and the direct learning control class has an average difference of 7.7 which is greater than LSD which is 6.52. This means that the NHT experimental class is more effective than the direct learning control class for learning outcomes. Summary of LSD Test Results can be seen in Table 6 below.

Table 6. Summary of LSD Test Results

\begin{tabular}{|c|c|c|c|}
\hline Compared Class & Different Mean & LSD & Info \\
\hline$\left|\bar{y}_{1}-\bar{y}_{2}\right|$ & 6,84 & 6,58 & More Effective \\
\hline$\left|\bar{y}_{1}-\bar{y}_{3}\right|$ & 14,54 & 6,58 & More Effective \\
\hline$\left|\bar{y}_{2}-\bar{y}_{3}\right|$ & 7,7 & 6,52 & More Effective \\
\hline
\end{tabular}

This study aims to compare the effectiveness of the learning model using the TAI learning model and the NHT learning model on mathematics learning outcomes and direct learning models. Analysis of pretest data on the results of the initial mathematical abilities obtained by the class average of the Type TAI learning model was 38.49 with no students reaching the KKM. The average class of the NHT type learning model is 42,292 with no students reaching KKM. While the average class of direct learning models is 42.5 with no students reaching KKM.

Analysis of the posttest data on the final mathematics learning outcomes obtained by the average class of the Type TAI learning model was 78.925 with $77.42 \%$ having reached the KKM and $22.58 \%$ not reaching the KKM. The class average of the NHT type learning model is 72,083 with $34,375 \%$ reaching the KKM and 65,625\% not reaching the KKM. While the average class of direct learning models is 64.375 with $18.75 \%$ having reached KKM and $81.25 \%$ not reaching KKM. Based on the description of the results of the pretest and posttest it can be seen that there is an increase in students' mathematics learning outcomes.

The hypothesis testing phase uses a complete randomized design with Anava test on the learning outcomes of mathematics at the pretest obtained: $F_{\text {count }}=1,361583$ and $F_{\text {table }}=3,10733$ then $F_{\text {count }}>F_{\text {table }}$. which means the value of the initial mathematics learning outcomes of students from the TAI Type experiment class, NHT type and direct are the same.

Whereas the hypothesis of posttest data on students' mathematics learning outcomes is obtained: $F_{\text {count }}=9,70214$ and $F_{\text {table }}=3,10733$ then $F_{\text {count }}>F_{\text {table }}$. which means there are differences in student learning outcomes using problem-based cooperative learning type TAI model, NHT type cooperative learning model, and direct learning model. To find out which approach is more effective, a test after Anava is used, namely the LSD test. The results of the LSD test state that the cooperative learning 
model of the TAI-based problem type is more effective in improving the mathematics learning outcomes of class VII students of SMP 3 Jetis Bantul in the academic year 2015/2016.

Based on the data obtained from the pretest and posttest mathematics learning outcomes of students in Jetis Bantul Middle School 3 it can be concluded that the use of problem-based cooperative learning models in class VII B is more effective than the cooperative learning type NHT model in class VII A and models direct learning in class VII C. This can be indicated by changes in the percentage of achievement of KKM mathematics learning outcomes achieved by students. It can be seen that all experienced increases, but the most significant increase in the TAI type of problem-based cooperative class models. This is because the cooperative learning model is a problem-based type of learning that is students are given the freedom to determine the problem situation, while the cooperative learning model of NHT type is given the answer, as well as direct learning where students are always centered on the teacher.

Table 7. Summary of KKM Achievement Percentages of Student Mathematics Learning Outcomes

\begin{tabular}{|c|c|c|}
\hline Class & $\begin{array}{c}\text { The Percentage Of Students } \\
\text { Is More Than KKM }\end{array}$ & $\begin{array}{c}\text { The Percentage Of Students } \\
\text { Is Less Than KKM }\end{array}$ \\
\hline Type TAI & $77,42 \%$ & $22,58 \%$ \\
\hline Type NHT & $34,375 \%$ & $65,625 \%$ \\
\hline Direct & $18,75 \%$ & $81,25 \%$ \\
\hline
\end{tabular}

\section{CONCLUSION}

1. There are differences in students' learning outcomes in learning using the Type TAI cooperative learning model with a problem-based approach, the NHT cooperative learning model and the direct learning model in class VII SMPN 3 Jetis Bantul District 2015/2016 academic year.

2. Learning using cooperative learning models The type of TAI is more effective than learning using cooperative learning models The NHT type and cooperative learning model The NHT type is more effective than the direct learning model of mathematics learning outcomes in class VII students of SMPN 3 Jetis Bantul, 2015/2016.

\section{REFERENCES}

Hafid, Anwar. 2013. Konsep Dasar Ilmu Pendidikan. Bandung : Alfabeta.

Hamzah, Ali. 2014. Perencanaan dan Strategi Pembelajaran Matematika. Jakarta: Raja Grafindo Persada Huda, Miftahul. 2013. Model-model pengajaran dan pembelajaran. Yogyakarta : Pustaka Pelajar.

Ibrahim dan Suparni. 2008. Strategi Pembelajaran Matematika. Yogyakarta: Bidang Akademik UIN Sunan Kalijaga.

Isjoni. 2010. Pembelajaran Kooperatif. Yogyakarta : Pustaka Pelajar

Mulyasa. 2005. Manajemen Berbasis Sekolah Konsep, Strategi, danImplementasi.Bandung: Remaja Rosdakarya.

Purwanto. Ngalim. 1984. Prinsip-prinsip dan Teknik Evaluasi Pengajaran. Jakarta. Remaja Rosdakarya. Shoimin, Aris. 2014. 68 Model Pembelajaran Inovatif dalam kurikulum 2013. Yogyakarta : Ar-Ruzz Media

Suherman, Erman dkk. 2003. Strategi Pembelajaran Matematika Kontemporer. Bandung: Universitas Pendidikan Indonesia.

Suprijono, Agus. 2009. Cooperative Learning Teori \& Aplikasi Paikem. Yogyakarta : Pustaka Pelajar. 